\title{
Selection of Indicators to Discriminate Soil Tillage Systems and to Assess Soil Quality in a Red Latosol
}

\section{Regiane Kazmierczak ${ }^{1}$ \\ https://orcid.org/0000-0002-7802-899X}

Neyde Fabíola Balarezo Giarola ${ }^{1}$

https://orcid.org/0000-0001-5240-9033

Flávia Biasso Riferte ${ }^{1}$

https://orcid.org/0000-0003-1184-7824

\author{
Josiane Burkner dos Santos ${ }^{2}$ \\ https://orcid.org/0000-0003-1252-869X
}

Alisson Marcos Fogaça ${ }^{1}$

https://orcid.org/0000-0002-7520-7271

\author{
Sandoval Carpinelli ${ }^{1}$ \\ https://orcid.org/0000-0002-4391-190X
}

${ }^{1}$ State University of Ponta Grossa, Ponta Grossa, Paraná, Brazil; 2Agronomic Institute of Paraná, Ponta Grossa, Paraná, Brazil.

Received: 2019.08.14; Accepted: 2020.02.20.

*Correspondence: regianekazmi@gmail.com; Tel.: +55-42-988480727 (F.L.).

HIGHLIGHTS

- The canonical discriminant analysis was used to identify sensible indicators of soil quality.

- $\mathrm{MiP}, \mathrm{K}_{\mathrm{fs}}, \mathrm{pH}\left(\mathrm{CaCl}_{2}\right), \mathrm{Ca}, \mathrm{Mg}, \mathrm{CEC}$ e BS were the indicators that best discriminate the NT, CT and MT.

- $\mathrm{MiP}, \mathrm{K}_{\mathrm{fs}}, \mathrm{BS}$ e $\mathrm{pH}\left(\mathrm{CaCl}_{2}\right)$ were the indicators recommended for soil quality assessment.

\begin{abstract}
The soil tillage practiced over a long period of time impacts soil quality. The first step in soil quality assessment is to select which indicators should be used. The objective of this study was to identify the soil attributes that discriminate soil tillage systems and can be used as indicators for soil quality assessments. Sixteen soil physical and chemical attributes were evaluated: macroporosity (MaP), microporosity (MiP), total porosity (TP), bulk density $(\mathrm{BD})$, field-saturated hydraulic conductivity $\left(\mathrm{K}_{\mathrm{fs}}\right)$, soil resistance to penetration (SRP), pH $\left(\mathrm{H}_{2} \mathrm{O}\right), \mathrm{pH}\left(\mathrm{CaCl}_{2}\right)$, aluminium $(\mathrm{Al})$, calcium $(\mathrm{Ca})$, magnesium $(\mathrm{Mg})$, potassium (K), available phosphorus $(\mathrm{P})$, total organic carbon (TOC), cation exchange capacity (CEC) and base saturation (BS), of a very clayey Red Latosol, cultivated for a long period in no-till (NT), conventional tillage (CT) and minimum tillage (MT). The soil attributes (indicators) were selected using canonical discriminant analysis. MiP, $\mathrm{K}_{\mathrm{fs}}, \mathrm{pH}$ $\left(\mathrm{CaCl}_{2}\right), \mathrm{Ca}, \mathrm{Mg}, \mathrm{CEC}$ e BS were the most efficient indicators to discriminate soil tillage systems. In the indicator interpretation step was sustained MiP as the indicator that represents the function of physical stability and support, $\mathrm{K}_{\mathrm{fs}}$ as the indicator that represents the function of water relations, $\mathrm{BS}$ as the indicator that represents the function of nutrient cycling and $\mathrm{pH}\left(\mathrm{CaCl}_{2}\right)$ as the indicator that represents the function of filtering and buffering. These indicators can be used for future soil quality assessment and monitoring of tillage systems in similar regions and conditions.
\end{abstract}

Keywords: sensible indicators; canonical discriminant analysis; long period experiment. 


\section{INTRODUCTION}

The concept of soil quality expanded from the early 1990s along with the global awareness of the importance of soil for agricultural sustainability and environmental quality. It was conceptualized as the capacity of specific kind of soil to function within natural or managed ecosystem limitations, to sustain plant and animal productivity, maintain environmental quality and support human health and habitation [1, 2]. Since then, the need to select, understand and evaluate indicators for soil quality assessment has been studied in soil science $[3,4]$.

In brief, we can define the soil quality as the capacity of the soil to function. In agricultural conditions, it is important to monitor whether the soil is performing its functions. Some important soil functions include nutrient cycling, water relations, physical stability and support, filtering and buffering, resistance and resilience, biodiversity and habitat, needed to meet a management goal: plant productivity, waste recycling, environmental protection [5,6]. For soil quality assessment it is necessary to integrate chemical, physical and biological soil indicators [7], because each soil function has associated chemical, physical and biological processes, and can be measured from the soil quality indicators [5].

The soil quality indicators are properties and processes that have the greatest sensitivity to changes in soil function [6] and should be sensitive to changes by tillage [4]. Therefore, a selection is required to identify a relevant set of indicators for soil quality assessment. $[8,9]$ that represent soil functions and be sensitive to changes in tillage [5]. Thus, the first step in soil quality assessment is performed by composing a minimum data set (MDS), reducing the number of attributes measured which reduces time and cost in future soil quality assessment $[10,11]$. Many studies present mathematical methods for selecting indicators based on sensitivity and not redundancy of indicators for soil quality assessment $[12,11,13,14,9]$.

To select the indicators, the canonical discriminant analysis (CDA) can be used. This helps to identify the indicators that most discriminate the soil tillage systems [15]. The CDA returns linear functions of quantitative variables called canonical discriminant functions (CDF). The scores resulted from the functions can be correlated with the original variables to identify significant indicators. [16, 15]. This analysis has an advantage over the principal component analysis (PCA) because CDA maximizes the variation between and minimizes the variation within groups of individuals and PCA ignores the structure of groups of the dataset [17]. The CDA has been used to discriminating organic and conventional coffee production systems [18], find the indicators that most discriminate soil management systems [19], distinguish among pesticides which had a prominent role for the segregation of classes [20], and select indicators that discriminated well three agroecosystems [21].

The soil tillage aims to improve soil conditions for crop establishment and development and influence the soil quality [22]. The soil indicators can be affected in different proportions, depending on the soil tillage system. The conventional tillage (CT) is a traditional tillage system characterized by the use of plowing and narrowing with the incorporation of plant residues and no-till (NT) is a conservation tillage that differs from the traditional tillage in terms of operations, with no soil disturbance. The CT was dominant in Brazil during the twentieth century. However, for reason of soil degradation by conventional plow-based tillage, there was a growing interest in adopting NT. However, the compaction of the superficial soil layer can seriously jeopardize the sustainability of NT [23] and, for that reason, the minimum tillage (MT) started to be adopted, because less intensive soil tillage is performed compared to CT $[24,25]$.

The local climate, soil characteristics, and management will reflect on how the soil performs its functions. Thus, for different conditions, there may be a greater or lesser influence of a given soil indicator [26]. The objective of this paper was to identify, using CDA, the physical and chemical soil attributes that discriminate soil tillage systems and can be used as indicators for soil quality assessments in a very clayey Red Latosol in the subtropical climate.

\section{MATERIAL AND METHODS}

\section{Experimental site and management}

The field experiments were conducted at the experimental station of IAPAR (Agronomic Institute of Parana), located in the city of Ponta Grossa, in the South-central region of the State of Parana, Brazil, (2509'06.2"S, 5009'15.19'W, $862 \mathrm{~m}$ above the sea level) in a very clayey Red Latosol (Brazilian classification [27], Oxisol for Soil Taxonomy, USDA classification) (726; 212 and $62 \mathrm{~g} \mathrm{~kg}^{-1}$ of clay, silt and sand, respectively). This soil is formed from Ponta Grossa Formation, with the presence of the following 
minerals: gibbsite, kaolinite, halloysite, montmorillonite, hematite, rutile, anatase, goethite and quartz [28]. The climate of the region is Cfb (humid subtropical, without dry season) according to Koppen's classification [29].

The three tillage systems consist of conventional tillage (CT): a plow tillage followed by two narrow disking after summer and winter harvest; minimum tillage (MT): comprising of one chisel plow and one narrow disking after summer and winter harvest; no-till (NT): no soil disturbance. In 1981 the experiment began, initially by conducting two tillage systems: NT and CT (Figure 1). In 1989, the area of CT was divided to perform the MT in the same place of study. Currently, the areas of each preparation system are $10000 \mathrm{~m}^{2}$ for NT; $5000 \mathrm{~m}^{2}$ for MT and $5000 \mathrm{~m}^{2}$ for CT. In 2017 soil samples were obtained and analyzed, with a history of 36 years under NT, 36 years under CT and 28 years under MT.

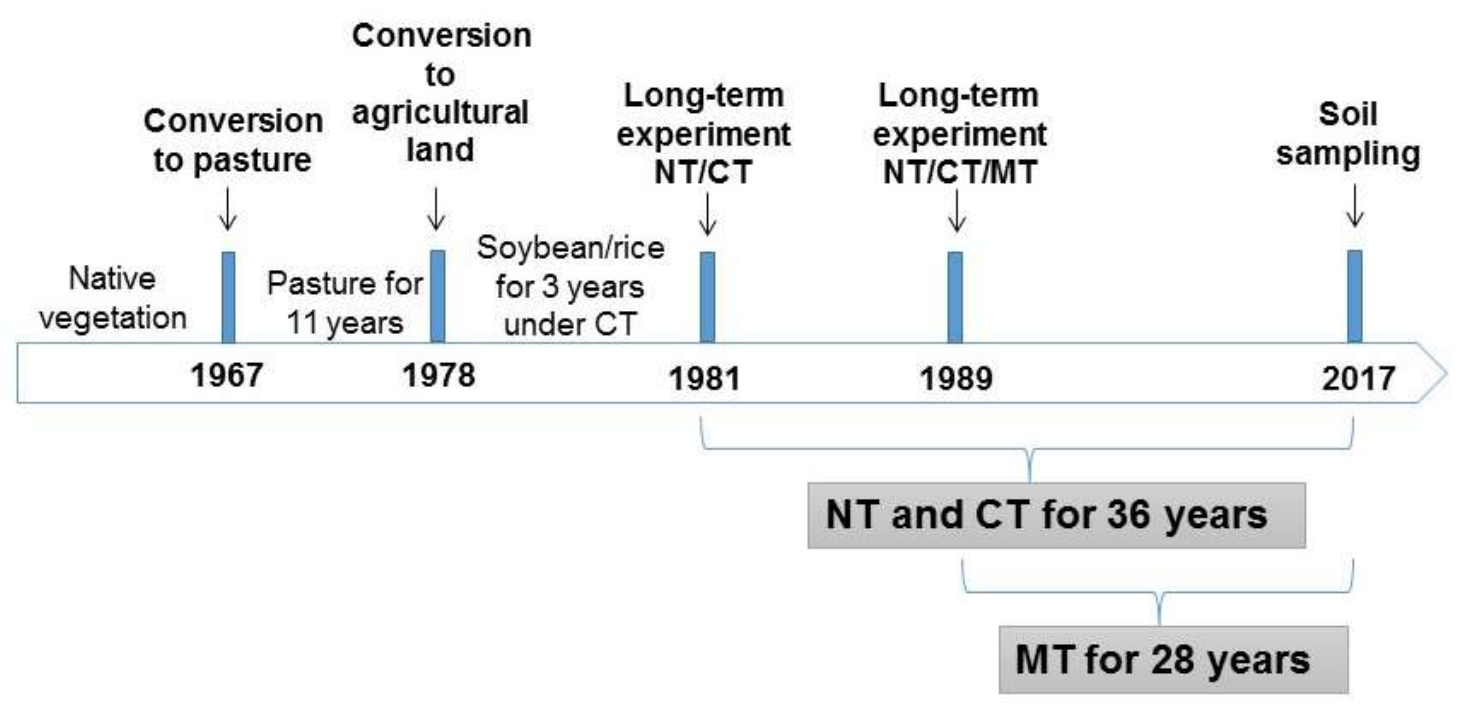

Figure 1. Chronology of land use in the experimental area at the IAPAR, city of Ponta Grossa, in the South-central region of the State of Parana, Brazil.

The cultures cultivated from the beginning of the experimental period were: (i) succession of soybean (Glycine max (L.) Merr.) and maize (Zea mays L.) during the spring-summer; (ii) succession of black oat (Avena strigosa Schreb), wheat (Triticum aestivum L.), common vetch (Vicia sativa L.) and intercropping of black oat and common vetch during the autumn-winter. Previous of the soil sampling (from 2012 to 2017) the following crops were cultivated: (i) soybean during the spring-summer of 2012-2013, 2014-2015, and 20162017 and maize during the spring-summer of 2013-2014 and 2015-2016; (ii) intercropping of black oat + common vetch in 2013 during the autumn-winter and black oat from 2014 to 2017 during the autumn-winter. The same crops were cultivated on all soil tillage systems.

\section{Soil sampling and analysis}

The soil sampling and analysis occurred after the spring-summer harvest. The samples were collected in a regular grid of $10 \times 5 \mathrm{~m}$ with regularly spaced lines of $10 \mathrm{~m}$, resulting in 50 samples per soil tillage system, in the depth of $0-0.1 \mathrm{~m}$. On each grid point, the soil samples were collected under a radius of one meter. Disturbed samples were used for chemical analyses and undisturbed samples (cylinders of $0.05 \times 0.05 \mathrm{~m}$ ) were used for physical analyses.

The undisturbed soil samples were saturated by capillary rise and then used to determine the macroporosity (MaP) under a tension of $-6 \mathrm{kPa}$ on sand table. After oven drying the samples at $105{ }^{\circ} \mathrm{C}$, it was determined the microporosity (MiP), total porosity (TP), and bulk density (BD) [30]. The disturbed soil samples were oven-dried at $40^{\circ} \mathrm{C}$ and utilized to the chemical analyses determination of $\mathrm{pH}\left(\mathrm{H}_{2} \mathrm{O}\right), \mathrm{pH}$ $\left(\mathrm{CaCl}_{2}\right)$, aluminium $(\mathrm{Al})$, calcium $(\mathrm{Ca})$, magnesium $(\mathrm{Mg})$, potassium $(\mathrm{K})$ [31], available phosphorus $(\mathrm{P})$ [32], total organic carbon (TOC) (Walkey-Black method) [33], and it was calculated the cation exchange capacity (CEC) and base saturation (BS).

Field-saturated hydraulic conductivity $\left(\mathrm{K}_{\mathrm{fs}}\right)$ was measured using the simplified falling-head method [34]. A ring infiltrometer of $0.198 \mathrm{~m}$ diameter was pressed $0.05 \mathrm{~m}$ into the soil, and a pre-established volume of 
water $(0.5 \mathrm{~L})$ was poured on the soil surface, then the infiltration time was measured. The a parameter utilized to calculate $\mathrm{K}_{\mathrm{fs}}$ was 12 [35] due to the soil defined structure and infiltration time less than 5 minutes. The soil resistance to penetration (SRP) was measured in the filed with a penetrometer penetroLog (Falker, BR), using cone type $03\left(7.94 \mathrm{~mm}\right.$ diameter and $\left.30^{\circ}\right)$ and a rod of $0.4 \mathrm{~m}$. The volumetric soil moisture was measure using the sensor Delta T Devices ML2 (Moisture Meter).

\section{Statistical analysis}

The analyses were done using the software $\mathrm{R}$ [36]. First, it was verified the presence of outliers and after its exclusion, it was kept 42 observations per tillage system. It was verified the univariate normality of the attributes with the Shapiro-Wilk's test and the multivariate normality by Royston's test. The data that did not show normality was transformed by squared root or natural logarithm to meet the normality premise.

It was utilized the package candisc [37] to perform the CDA on two steps [15], (i) all attributes were added on the discrimination procedure and it was obtained the canonical discriminant functions (CDF), those were assessed for its significance by the Wilks' Lambda $(p<0.05)$. The indicators with significant correlation $(r<0.70)$ with the scores of the CDF were selected to follow to the second step, (ii) the selected indicators were resubmitted to the CDA and the indicator with the highest coefficients on the CDF were selected. It was procedure analysis of variance (ANOVA) of the scores of the CDF, if significant $(p<0.05)$ the differences of the means were assessed using the Tukey's test $(p<0.05)$.

\section{RESULTS}

The means and standard error of physical and chemical attributes are shown in Table 1. The physical attributes that presented the highest ratio of the standard errors with the mean were $\mathrm{K}_{\mathrm{fs}}$, SRP, and MaP; and the chemical attributes were $\mathrm{P}, \mathrm{K}$, and Al. The physical attributes that presented the lowest ratio of the standard error with the mean were TP, BD, and MiP and the chemical attributes were $\mathrm{pH}\left(\mathrm{H}_{2} \mathrm{O}\right.$ and $\left.\mathrm{CaCl}_{2}\right)$, CEC, and TOC. 
Table 1. Descriptive statistics for 42 physical and chemical attributes of soil with means, standard error, Shapiro-Wilk's univariate normality test and Royston's multivariate normality test.

\section{Physical attributes}

\begin{tabular}{lcccccc}
\hline & BD & TP & MaP & MiP & $\begin{array}{c}\mathbf{K}_{\mathrm{fs}} \\
\mathrm{cm} \mathrm{min}^{-1}\end{array}$ & $\begin{array}{c}\text { SRP } \\
\text { Mpa }\end{array}$ \\
\hline $\mathrm{NT}^{1}$ & $1.03 \pm 0.05$ & $62.40 \pm 2.15$ & $10.82 \pm 3.75$ & $51.58 \pm 3.24$ & $1.19 \pm 0.74$ & $1.39 \pm 0.57$ \\
$\mathrm{MT}^{1}$ & $1.02 \pm 0.07$ & $62.38 \pm 2.50$ & $17.69 \pm 5.08$ & $44.70 \pm 2.95$ & $3.77 \pm 2.31$ & $0.60 \pm 0.37$ \\
$\mathrm{CT}^{1}$ & $1.02 \pm 0.06$ & $62.91 \pm 2.29$ & $21.11 \pm 4.90$ & $41.80 \pm 2.91$ & $6.30 \pm 3.13$ & $0.61 \pm 0.29$ \\
\hline
\end{tabular}

Shapiro-Wilk's statistics ${ }^{2}$

\begin{tabular}{lcccccc} 
Statistic & 0.99 & 0.99 & 0.98 & 0.98 & 0.99 & 0.99 \\
p-value & 0.65 & 0.28 & 0.10 & 0.07 & 0.20 & 0.59 \\
\hline
\end{tabular}

\section{Chemical attributes}

\begin{tabular}{lccccc}
\hline & $\mathbf{p H}$ & $\mathbf{p H}$ & $\mathbf{A l}$ & $\mathbf{C a}$ & $\mathbf{M g}$ \\
& $\mathrm{H}_{2} \mathrm{O}$ & $\mathrm{CaCl}_{2}$ & - & $-\cdots$ & \\
\hline $\mathrm{NT}^{1}$ & $4.58 \pm 0.13$ & $3.96 \pm 0.07$ & $1.40 \pm 0.31$ & $2.24 \pm 0.47$ & $1.83 \pm 0.35$ \\
$\mathrm{MT}^{1}$ & $4.83 \pm 0.10$ & $4.22 \pm 0.08$ & $0.75 \pm 0.23$ & $3.50 \pm 0.85$ & $3.82 \pm 0.65$ \\
$\mathrm{CT}^{1}$ & $4.69 \pm 0.12$ & $4.12 \pm 0.09$ & $1.05 \pm 0.32$ & $2.05 \pm 0.52$ & $1.40 \pm 0.35$ \\
\hline
\end{tabular}

Shapiro-Wilk's statistics ${ }^{2}$

\begin{tabular}{lccccc} 
Statistic & 0.99 & 0.99 & 0.98 & 0.99 & 0.99 \\
p-value & 0.70 & 0.49 & 0.06 & 0.24 & 0.71 \\
\hline & $\mathbf{K}$ & $\mathbf{P}$ & TOC & $\mathbf{C E C}$ & $\mathbf{B S}$ \\
& $\mathrm{cmol}_{\mathrm{c}} \mathrm{dm}^{-3}$ & $\mathrm{mg} \mathrm{dm}^{-3}$ & $\mathrm{~g} \mathrm{dm}^{-3}$ & $\mathrm{cmol}_{\mathrm{c}} \mathrm{dm}^{-3}$ & $(\%)$ \\
\hline NT & $0.31 \pm 0.08$ & $1.20 \pm 0.56$ & $30.23 \pm 1.61$ & $19.25 \pm 0.66$ & $22.74 \pm 2.72$ \\
MT & $0.34 \pm 0.10$ & $0.88 \pm 0.60$ & $29.86 \pm 2.40$ & $20.75 \pm 1.10$ & $36.80 \pm 3.20$ \\
CT & $0.28 \pm 0.10$ & $0.43 \pm 0.29$ & $29.37 \pm 2.04$ & $17.44 \pm 0.68$ & $21.41 \pm 4.09$
\end{tabular}

\begin{tabular}{|c|c|c|c|c|c|}
\hline Statistic & 0.98 & 0.99 & 0.99 & 0.99 & 0.98 \\
\hline p-value & 0.14 & 0.29 & 0.70 & 0.32 & 0.17 \\
\hline
\end{tabular}

Royston statistics ${ }^{3}$

Statistic

12.08

p-value

0.23

${ }^{1}$ Means and standard error for bulk density (BD), total porosity (TP), macroporosity (MaP), microporosity (MiP), saturated hydraulic conductivity $\left(\mathrm{K}_{\mathrm{fs}}\right)$, soil resistance to penetration $(\mathrm{SRP}), \mathrm{pH}\left(\mathrm{H}_{2} \mathrm{O}\right)$ and $\left(\mathrm{CaCl}_{2}\right)$, aluminium $(\mathrm{Al})$, calcium $(\mathrm{Ca})$, magnesium $(\mathrm{Mg})$, potassium $(\mathrm{K})$, phosphorus $(\mathrm{P})$ available, total organic carbon $(\mathrm{TOC})$, cation exchange capacity (CEC), and base saturation (BS) in different soil tillage systems (no-till = NT; minimum tillage $=M T$; conventional tillage $=\mathrm{CT}$ ). ${ }^{2}$ Shapiro-Wilk's univariate normality test (Square root of $\mathrm{P}$ and logarithm of SRP, $\mathrm{K}_{\mathrm{fs}}$, and $\mathrm{K}$ ). ${ }^{3}$ Royston's multivariate normality test.

The physical attributes that did not show normality were SRP and $\mathrm{K}_{\mathrm{fs}}$ and the chemical attributes that did not show normality were $\mathrm{K}$ and $\mathrm{P}$. The latter was transformed by square root and the others by logarithm. Then, it was verified univariate normality by the Shapiro-Wilk' test for each variable (Table 1) and multivariate normality by the Royston' test (Table 1 ).

In the first step of the CDA, the two CDF obtained were significant according to the Wilks' Lambda test (Table 2). Significant correlations between the scores of the first CDF and the original attributes occurred for $\mathrm{MiP}$ e $\mathrm{K}_{\mathrm{fs}}$, showing a negative and positive correlation, respectively. The strongest correlations between the 
scores of the second CDF and the original attributes occurred for $\mathrm{pH}\left(\mathrm{CaCl}_{2}\right), \mathrm{Ca}, \mathrm{Mg}, \mathrm{CEC}$ e $\mathrm{BS}$, showing positive values for all these attributes.

Table 2. Significance, eigenvalue and correlation coefficients between canonical discriminant functions and the physical and chemical attributes in the first step.

\begin{tabular}{|c|c|c|}
\hline & CDF 1 & CDF 2 \\
\hline$F$ & 63.52 & 56.79 \\
\hline Significance $^{1}$ & $2.20 E-16$ & $2.20 \mathrm{E}-16$ \\
\hline Eigenvalue & 11.29 & 7.81 \\
\hline $\mathrm{BD}\left(\mathrm{g} \mathrm{cm}^{-3}\right)$ & -0.08 & -0.02 \\
\hline TP (\%) & 0.10 & -0.05 \\
\hline $\operatorname{MaP}(\%)$ & 0.69 & 0.20 \\
\hline $\operatorname{MiP}(\%)$ & $-0.80^{\star}$ & -0.27 \\
\hline $\mathrm{K}_{\mathrm{fs}}\left(\mathrm{cm} \mathrm{min} \mathrm{min}^{-1}\right)$ & $0.78^{*}$ & 0.23 \\
\hline SRP (Mpa) & -0.54 & -0.43 \\
\hline $\mathrm{pH}\left(\mathrm{H}_{2} \mathrm{O}\right)$ & 0.24 & 0.65 \\
\hline $\mathrm{pH}\left(\mathrm{CaCl}_{2}\right)$ & 0.45 & $0.72^{*}$ \\
\hline $\mathrm{Al}\left(\mathrm{cmol}_{\mathrm{c}} \mathrm{dm}^{-3}\right)$ & -0.33 & -0.64 \\
\hline $\mathrm{Ca}\left(\mathrm{cmol}_{\mathrm{c}} \mathrm{dm}^{-3}\right)$ & -0.16 & $0.74^{\star}$ \\
\hline $\mathrm{Mg}\left(\mathrm{cmol}_{\mathrm{c}} \mathrm{dm}^{-3}\right)$ & -0.24 & $0.94^{\star}$ \\
\hline$P\left(\mathrm{mg} \mathrm{dm}^{-3}\right)$ & -0.57 & -0.03 \\
\hline $\mathrm{K}\left(\mathrm{cmol}_{\mathrm{c}} \mathrm{dm}^{-3}\right)$ & -0.21 & 0.22 \\
\hline $\mathrm{TOC}\left(\mathrm{g} \mathrm{dm}^{-3}\right)$ & -0.18 & 0.00 \\
\hline CEC $\left(\mathrm{cmol}_{\mathrm{c}} \mathrm{dm}^{-3}\right)$ & -0.55 & $0.71^{*}$ \\
\hline BS (\%) & -0.16 & $0.95^{\star}$ \\
\hline
\end{tabular}

1 Probability of the correlation of the scores of the CDF with the attributes to be null.

*Correlations above 0.7 were selected.

In the second step, the two CDF obtained were significant according to the Wilks' Lambda test (Table 3 ). The CDF 1 represented $53.06 \%$ of the total variance with the highest coefficient for MiP and secondhighest for $\mathrm{K}_{\mathrm{fs}}$, both physical processes of the soil. A high and positive score of this CDF 1 indicates that the soil tillage system shows conditions of low MiP and high $\mathrm{K}_{\mathrm{fs}}$ (Figure 2). The CDF 2 represented $46.94 \%$ of the total variance showing the highest coefficient for $\mathrm{Mg}$ and $\mathrm{BS}$, followed by $\mathrm{Ca}, \mathrm{CEC}$ and $\mathrm{pH}\left(\mathrm{CaCl}_{2}\right)$, represented soil chemical processes. A high and positive score of this CDF for the soils under a given soil tillage system signalize that the soil have high values for all these indicators (Figure 3). 
Table 3. Significance, eigenvalue and correlation coefficients between canonical discriminant functions and the physical and chemical attributes in the first step.

\begin{tabular}{lll}
\hline & CDF 1 & CDF 2 \\
\hline F & 120.98 & 133.85 \\
Significance & & $2.20 \mathrm{E}-16$ \\
Eigenvalue & $2.2 \mathrm{E}-16$ & 6.8 \\
$\mathrm{MiP}(\%)$ & 7.69 & -0.23 \\
$\mathrm{~K}$ fs $\left(\mathrm{cm} \mathrm{min}^{-1}\right)$ & -0.83 & 0.19 \\
$\mathrm{pH}\left(\mathrm{CaCl}_{2}\right)$ & 0.80 & 0.70 \\
$\mathrm{Ca}\left(\mathrm{cmol}_{\mathrm{c}} \mathrm{dm}^{-3}\right)$ & 0.50 & 0.75 \\
$\mathrm{Mg}\left(\mathrm{cmol}_{\mathrm{c}} \mathrm{dm}^{-3}\right)$ & -0.12 & 0.96 \\
$\mathrm{CEC}\left(\mathrm{cmol}_{\mathrm{c} \mathrm{dm}} \mathrm{dm}^{-3}\right)$ & -0.20 & 0.74 \\
$\mathrm{BS}(\%)$ & -0.52 & 0.96 \\
\hline
\end{tabular}

1 Probability of correlation of CDF scores with attributes to be 0 .

The Shapiro-Wilk' test showed normality of the scores of the CDF $1(p=0.8852)$ and the ANOVA indicated significance for CDF 1 scores $(p<2 e-16)$. Mean scores of the three tillage were significantly different by the Tukey' test, showing the highest mean for CT, the lowest mean for NT and the intermediate mean for MT (Figure 2).

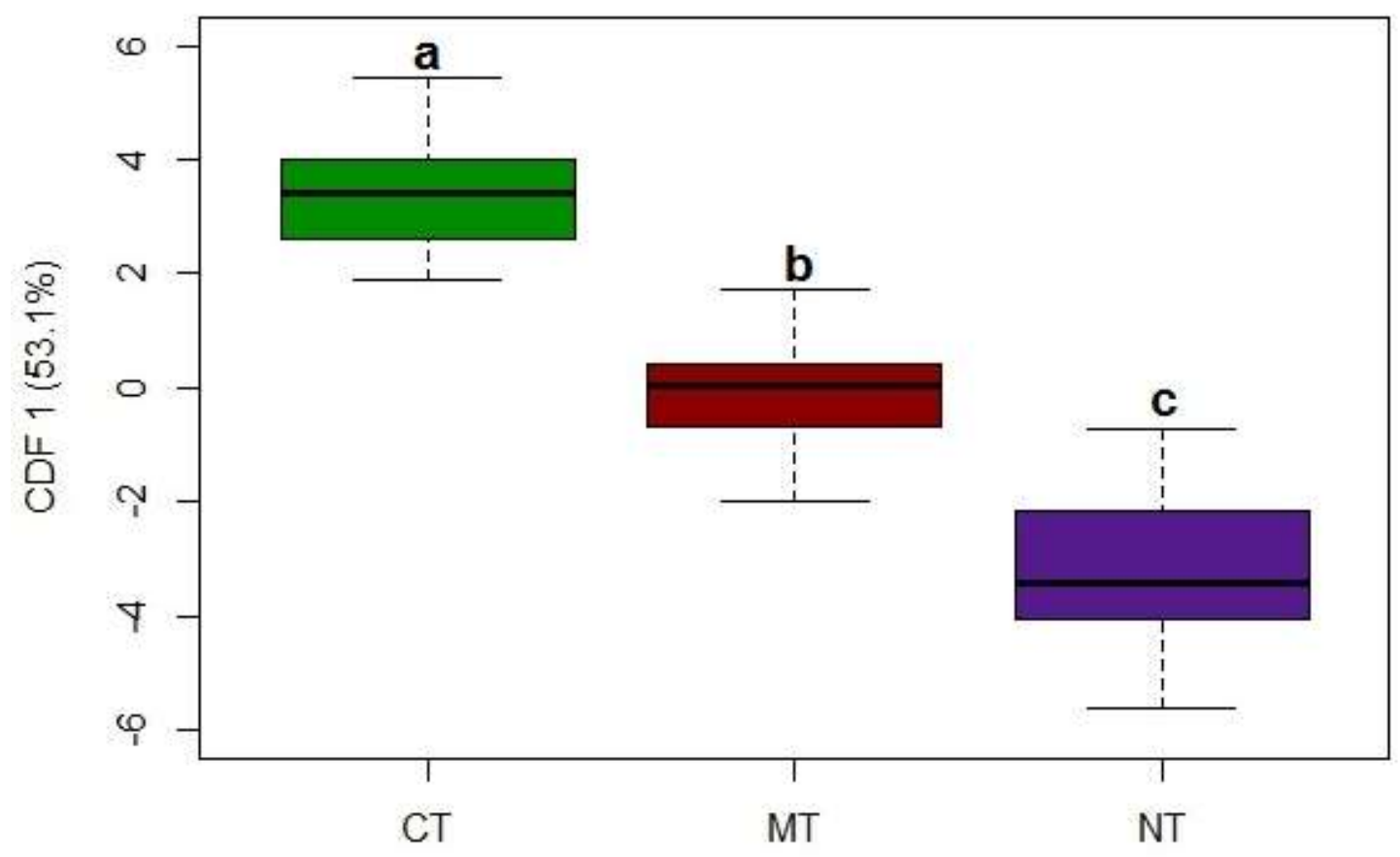

Figure 2. Boxplot graphs of the scores of the CDF 1 for the soil under the different tillage systems. Boxes followed by the same letter are not significantly different according to the Tukey's test at $p<0.05$. NT $=$ no-till; MT $=$ minimum tillage; $\mathrm{CT}=$ conventional tillage.

The Shapiro-Wilk' test showed normality of the scores of the CDF $2(p=0.8039)$. The tillage systems also influenced the variability of scores according to the ANOVA $(p<2 e-16)$. The mean CDF 2 scores of CT and NT did not differ according to the Tukey' test and were lower than the mean of the scores of the MT (Figure 3). 


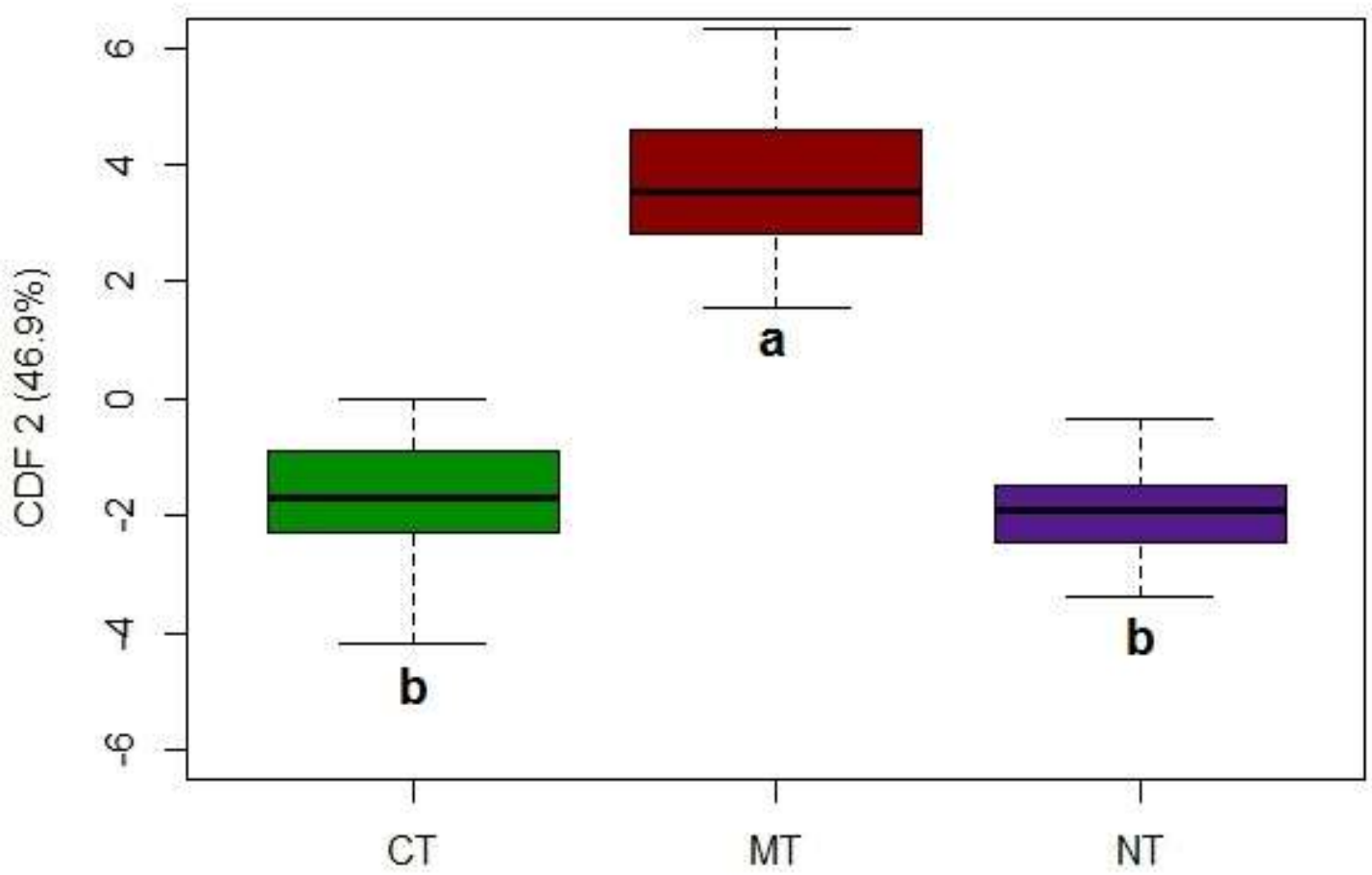

Figure 3. Boxplot graphs of the scores of the CDF 2 for the soil under the different tillage systems. Boxes followed by the same letter are not significantly different according to the Tukey's test at $p<0.05$. NT = no-till; MT = minimum tillage; $\mathrm{CT}=$ conventional tillage.

The Figure 4 illustrates the separation of NT, MT and CT.

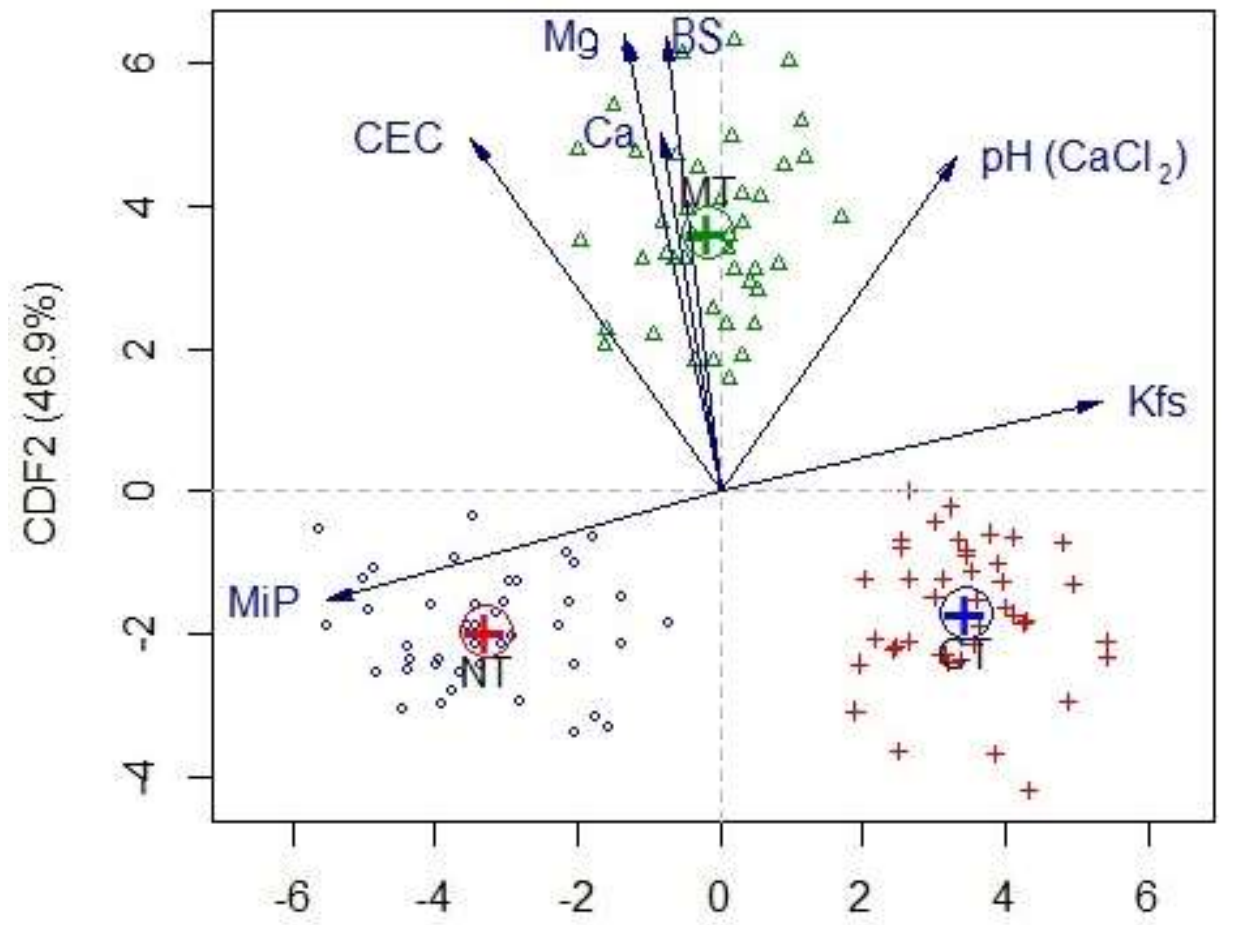

$\operatorname{CDF} 1(53.1 \%)$

Figure 4. Representation of group discrimination using variables selected by canonical discriminant functions. NT = notill; $\mathrm{MT}=$ minimum tillage; $\mathrm{CT}=$ conventional tillage . 


\section{DISCUSSION}

The CDA was efficient in selecting the indicators that most discriminate soil tillage systems and which can be used to soil quality assessment for its sensitivity. The CDF 1 reflects a linear combination of a group of physical indicators that are not correlated with the linear combination of a group of chemical indicators from the CDF 2. Absence of correlation between discriminant functions indicates that each CDF extracts a dimension of information from the data set [15].

\section{Indicators}

The CDF 1 indicates that the MiP and the $\mathrm{K}_{\mathrm{fs}}$ are strong discriminators of soil tillage systems and both indicate physical soil processes. These indicators are strongly and negatively correlated (Table 3), showing that both are sensitive but redundant and that soils that have a high value of one indicator will show low value of another. Interested in reducing the number of indicators measured, consider only the MiP is advantageous due to the higher correlation value with the scores of the CDF $1(-0.83)$, and the MiP presented lower variability compared to the $\mathrm{K}_{\mathrm{fs}}$ that required transformation for normalization (Table 1). The MiP represents the function of physical stability and support.

The MaP showed a high correlation (0.69) but $<0.70$ and was not selected. The MaP showed greater variability than MiP, pointing that MiP is a more stable indicator. The greater variability of MaP demonstrates that it is more unstable, requiring a larger number of soil samples for its representation. On the other hand, the low variability of MiP shows its greater stability, which characterizes it as a better indicator. This can be explained by the hierarchy of aggregation. Microaggregates contain micropore and these are more stable in soil $[5,37]$. Macropores are formed mainly between aggregates and are more easily altered by root action and tillage, and thus are more unstable in the soil, which leads to greater variability of MaP. The BD and TP presented low variability but were not sensitive to soil tillage systems. The SRP presented a few ability of discrimination of soil tillage systems (-0.54) and high data variability (Table 1), thus it was not selected due to the low correlation with the scores of the CDF $(<0.70)$.

Our data indicate that even showing a great variability, $\mathrm{K}_{\mathrm{fs}}$ differs substantially between the soil tillage systems (Table 3), pointing the potential of the use of it as a sensitive indicator for soil quality assessment. However, it needs a larger number of samples due to spatial variability and may present temporal variability $[38,39]$. The $\mathrm{K}_{\mathrm{fs}}$ is a dynamic soil indicator associated with water relations function. An advantage of using the $\mathrm{K}_{\mathrm{fs}}$ as an indicator is that it can be field determined, by simplified falling-head method, which was used in this study, reducing time and cost [34]. On the one hand the determination of MiP needs laboratory processes, requiring more time and specific equipment for its determination, but on the other hand it can be built with low cost [41]. Laboratory experiments can also be conducted to determine the $\mathrm{K}_{\mathrm{fs}}$, but it needs more time and specific equipment, as well as other techniques for field $\mathrm{K}_{\mathrm{fs}}$ determination such as pressure infiltrometer [40].

The CDF 2 signalizes that the chemical indicators were strong discriminators of soil tillage systems, represent soil chemical processes. Both of these chemical indicators $\left(\mathrm{pH}\left(\mathrm{CaCl}_{2}\right), \mathrm{Ca}, \mathrm{Mg}, \mathrm{CEC}\right.$ and $\left.\mathrm{BS}\right)$ are positively correlated. The BS and Mg showed the highest correlation between FDC 2 and the original data $(0,96)$ (Table 3).

$\mathrm{Ca}, \mathrm{Mg}, \mathrm{K}$, and $\mathrm{CEC}$ are used in the calculation of $\mathrm{BS}$, requiring these analytical determinations for $\mathrm{BS}$ to be calculated, which is more labor intensive than determining only $\mathrm{Mg}$. In addition to the strong discrimination of BS, it shows low variability and indicates the behavior and availability of various elements essential to plant development [42]. This indicator gives a more complete idea of soil fertility and it is the base measurement used for liming recommendation for the state of Parana [43]. Thus, BS is an indicator that can be maintained for soil quality assessment because includes $\mathrm{Ca}, \mathrm{Mg}$, and $\mathrm{CEC}$, which are also strong discriminators (Table 3 ) and can be associated with the function of nutrient cycling.

The BS is strongly and positively correlated with soil $\mathrm{pH}$ (Table 3), however, the $\mathrm{pH}$ provides information that BS does not provide, such as soil micronutrient availability to crops, aluminum balance and toxicity, decomposition of organic matter and many biological processes in soils [44]. Furthermore, the pH is an indicator that can represent the function of filtering and buffering, because the variation in soil $\mathrm{pH}$ alters the availability of toxic elements such as $\mathrm{Al}^{3+}$ and also micronutrients that in certain amounts in the soil are toxic to plants. The soil pH is a fast measure to obtain and showed low variability in this study. This indicator is largely used in soil quality assessment $[44,14,45,46,9]$. 
In this study, the $\mathrm{pH}\left(\mathrm{CaCl}_{2}\right)$ discriminated soil tillage systems more strongly than $\mathrm{pH}\left(\mathrm{H}_{2} \mathrm{O}\right)(\mathrm{Table} 2)$. The soil $\mathrm{pH}\left(\mathrm{CaCl}_{2}\right)$ is lower than soil $\mathrm{pH}\left(\mathrm{H}_{2} \mathrm{O}\right)$ because the addition of $\mathrm{CaCl}_{2}$ results in reduced $\mathrm{pH}$ due to the exchange of $\mathrm{Ca}^{2+}$ with $\mathrm{H}^{+}$and $\mathrm{Al}^{3+}$ on the solids surface [44]. The $\mathrm{pH}\left(\mathrm{CaCl}_{2}\right)$ may have been more sensitive than the $\mathrm{pH}\left(\mathrm{H}_{2} \mathrm{O}\right)$ because it is affected by soil CEC (Table 1), expressing CEC information in this indicator $\left(\mathrm{pH}\left(\mathrm{CaCl}_{2}\right)\right)$.

The TOC was not a sensitive indicator, despite being described as a good indicator of soil quality assessment [7] and showed low variability in our study. In clay soils, the flocculation of clay particles and stability of soil aggregation are advantaged. Consequently, there is physical protection provided by the occlusion of the carbon within the aggregates, hiding or preventing the access of microorganisms and their enzymes, and in micropores where even diffusive oxygen flow is difficult, there is greater preservation of carbon. Intrinsic soil properties, such as soil texture and mineral content, probably regulates the stabilization of TOC inputs by fine soil particles [48], demonstrating that TOC is dependent on soil texture and highly correlated with the quantity of fine soil particles [49]. Possibly the fractionation of TOC in particulate organic carbon (POC) and mineral-associated organic carbon (MAOC) could have a higher sensitivity to soil tillage systems than TOC. The POC represents a relatively small proportion of the TOC [48], but is easily decomposed and extremely sensitive to environmental variations [50]. The MAOC represents $50-80 \%$ of TOC and is stabilized by fine soil particles, being fundamental for the persistence of TOC in soil [48]. For soil quality assessment it is recommended to use at least one indicator representing each soil process (chemical, physical and biological) [51]. The TOC could represent the biological processes, however, does not present sensitivity, and then it is recommended to verify a more sensitive biological indicator for the soil quality assessment for the experimental condition.

\section{Tillage System}

The CDF 1 discriminated the three soil tillage systems (Figure 2, 4), marking that the physical indicators are the most efficient in this discrimination (MiP e $\mathrm{K}_{\mathrm{fs}}$ ). Between NT and $\mathrm{CT}$, the separation by physical indicators was greater. The soil tillage in CT increases the MaP and the $\mathrm{K}_{\mathrm{fs}}$, and NT has greater MiP than CT. This happens because in NT the agricultural operations may increase soil compaction in the superficial soil layer and there is no soil tillage for the reversing process [23], resulting in reduced MaP and increased MiP. MT is a less intensely soil tillage compared to CT with less soil manipulation, and incorporation of residues into the soil. On the other hand, compared to NT, MT increasing the MaP due to soil tillage, being the MT intermediate to CT and NT (Figure 04).

The physical indicators are important when comparing NT with CT and MT because these indicators are affected by soil tillage. It is common for the NT to present a higher MiP, and soil tillage in TC and MT increases $\mathrm{MaP}$ and $\mathrm{K}_{\mathrm{fs}}$ [24]. These indicators are related to soil structure [52]. Dynamic physical indicators as the $\mathrm{K}_{\mathrm{fs}}$ tend to be greatly affected by soil tillage [39]. The $\mathrm{K}_{\mathrm{fs}}$ is an important soil property because the higher the $\mathrm{K}_{\mathrm{fs}}$ the greater is the water infiltration and there is a lesser surface runoff, reducing erosion. However, the greater $\mathrm{K}_{\mathrm{fs}}$ can increase leaching of pesticides and nutrients from agricultural lands, and migration of pollutants from contaminated sites to the groundwater [34]. Our study showed that $\mathrm{K}_{\mathrm{fs}}$ is related to soil structure by its correlation with MiP, as found in other studies. [53].

The CDF 2 separated MT from CT and NT (Figure 3), being the chemical indicators the most efficient in this discrimination (Figure 4). The tendency of the NT is to present better fertility conditions in the superficial layers of the soil, but the best condition is verified mainly in the first $0.05 \mathrm{~m}$ of soil depth [54] due to the superficial deposition of fertilizers, lime, and organic residues. In CT the tendency is to find a lower but uniform fertility condition along the profile due to tillage (primary and secondary tillage operations), with higher oxidation of organic residues, higher nutrient leaching and erosion losses. [55], but in the present study there was no such effect, being the fertility found in CT similar to NT because the chemical conditions did not discriminate these systems (Figure 04). This result may be related to the soil depth considered in this study $(0-0.10 \mathrm{~m})$ and under NT is expected higher fertility in the most superficial soil depth $(0-0.05 \mathrm{~m})$. In addition, increased erosion soil losses that may occur in CT [56] but NT can increased water losses in extreme events due to low MaP and $\mathrm{K}_{\mathrm{fs}}$, and due to higher fertility in more superficial layers, nutrient losses tend to be high [57].

The MT differed from CT and NT presenting better soil fertility conditions. The MT results in intermediated soil physical conditions between CT and NT and this may also have favored chemical conditions. The higher $\mathrm{K}_{\mathrm{fs}}$ of MT when compared to NT may have affected the oxidation and reduction of the soil and consequently 
the soil $\mathrm{pH}$, by affecting the oxidation potential and reduction of the soil, what affects the nutrient dynamics [58]. Comparing MT with CT, MT can cause lower nutrient losses.

\section{CONCLUSION}

The indicators that most discriminate soil tillage systems in very clayey Red Latosol were: microporosity $(\mathrm{MiP})$, field-saturated hydraulic conductivity $\left(\mathrm{K}_{\mathrm{fs}}\right), \mathrm{pH}\left(\mathrm{CaCl}_{2}\right)$, calcium $(\mathrm{Ca})$, magnesium $(\mathrm{Mg})$, cation exchange capacity (CEC) and base saturation (BS).

For the soil quality assessment in soil tillage systems, it is recommended to use the MiP representing the function of physical stability and support, $\mathrm{K}_{\mathrm{fs}}$ representing the function of water relations, $\mathrm{BS}$ representing the function of nutrient cycling and $\mathrm{pH}\left(\mathrm{CaCl}_{2}\right)$ representing the function of filtering and buffering, in a very clayey Red Latosol in the subtropical climate.

Funding: This research was funded by Coordenação de Aperfeiçoamento de Pessoal de Nível Superior - Brasil (CAPES) - Financing Code 001.

Conflicts of Interest: The funders had no role in the design of the study; in the collection, analyses, or interpretation of data; in the writing of the manuscript, or in the decision to publish the results.

\section{REFERENCES}

1. Doran JW, Parkin TB. Defining and assessing soil quality. In: Doran JW, Coleman DC, Bezdicek DF, Stewart BA. Defining Soil Quality for a Sustainable Environment. Publisher: SSSA, Madison, WI, 1994; p. 3-21.

2. Karlen DL, Mausbach MJ, Doran JW, Cline RG, Harris RF, Schuman GE. Soil Quality: A Concept, Definition, and Framework for Evaluation. Soil Sci Soc Am J. 1997;61(1):4-10.

3. Cherubin MR, Eitelwein MT, Fabbris C, Weirich SW, Silva RF, Silva VR, Basso CJ. Qualidade física, química e biológica de um Latossolo com diferentes manejos e fertilizantes. Rev Bras Ciência do Solo. 2015;39:615-25.

4. Muñoz-rojas M. Soil quality indicators: critical tools in ecosystem restoration. Environ Sci Heal. 2018;5:47-52.

5. Weil RR, Brady NC. The nature and properties of soils. 15rd. Pearson Education; 2017. 1104 p.

6. Andrews SS, Karlen DL, Cambardella C. The Soil Management Assessment Framework: A Quantitative Soil Quality Evaluation Method. Soil Sci Soc Am J. 2004;68(6):1945-62.

7. Vezzani FM, Mielniczuk J. Uma visão sobre qualidade do solo. Rev Bras Cienc do Solo. 2009;33(4):743-55.

8. Kiani M, Hernandez-Ramirez G, Quideau S, Smith E, Janzen H, Larney FJ, Puurveen D. Quantifying sensitive soil quality indicators across contrasting long-term land management systems: Crop rotations and nutrient regimes. Agric Ecosyst Environ. 2017;248:123-35.

9. Valle SR, Carrasco J. Soil quality indicator selection in Chilean volcanic soils formed under temperate and humid conditions. Catena. 2018;162:386-95.

10.Bünemann EK, Bongiorno G, Bai Z, Creamer RE, De Deyn G, Goede R, Fleskens L, Geissen V, Kuyper TW, Mäder P, Pulleman M, Sukkel W, Van Groenigen JW, Brussaard L. Soil quality - A critical review. Soil Biol Biochem. 2018;120:105-25.

11. Raiesi F. A minimum data set and soil quality index to quantify the effect of land use conversion on soil quality and degradation in native rangelands of upland arid and semiarid regions. Ecol Indic. 2017;75:307-20.

12. Andrews SS, Karlen DL, Mitchell JP. A comparison of soil quality indexing methods for vegetable production systems in Northern California. Agric Ecosyst Environ. 2002;90(1):25-45.

13. Thoumazeau A, Bessou C, Renevier M, Trap J, Marichal R, Mareschal L, Decaëns T, Bottinelli N, Jaillard B, Chevallier T, Suvannang N, Sajjaphan K, Thaler P, Gay F, Brauman A. Biofunctool: a new framework to assess the impact of land management on soil quality. Part A: concept and validation of the set of indicators. Ecol Indic. 2019;97:100-10.

14.Zuber SM, Behnke GD, Nafziger ED, Villamil MB. Multivariate assessment of soil quality indicators for crop rotation and tillage in Illinois. Soil Tillage Res. 2017;174:147-55.

15.Cruz-Castillo JG, Ganeshanandam S, MacKay BR, Lawes GS, Lawoko CRO, Woolley DJ. Applications of Canonical Discriminant Analysis in Horticultural Research. Hortic Sci. 1994;29(10):1115-9.

16. Afifi AA, Clark V. Computer-aided multivariate analysis. New York: Van Nostrand; 1990.

17.Anderson MJ, Willis TJ. Canonical analysis of principal coodinates: a useful method of constrained ordination for ecology. Ecology. 2003;84(2):511-25. 
18. Azevedo Junior RR, Santos JB, Baretta D, Ramos AC, Otto R, Façanha AR, Cardoso EJBN. Discriminating organic and conventional coffee production systems through soil and foliar analysis using multivariate approach. Commun Soil Sci Plant Anal. 2019;50(6):651-61.

19. Silva AMM, Ramos MLG, Nascimento RSMP, Silva AN, Silva SB, Cardoso EJBN, Paula AM. Soil quality indicators under management systems in a Quilombola community in the Brazilian Cerrado. Sci Agric. 2019;76(6):518-26.

20.Gonçalves C, Esteves da Silva JCG, Alpendurada MF. Chemometric interpretation of pesticide occurence in soil samples from an intensive horticulture area in north Portugal. Anal Chim Acta. 2006;560:164-71.

21.Bhattacharjya S, Bhaduri D, Chauhan S, Chandra R, Raverkar KP, Pareek N. Comparative evaluation of three contrasting land use systems for soil carbon , microbial and biochemical indicators in North-Western Himalaya. Ecol Eng. 2017;103:21-30.

22. Barbosa MA, Ferraz RLS, Coutinho ELM, Neto AMC, Silva MS, Fernandes C, Rigobelo EC. Multivariate analysis and modeling of soil quality indicators in long-term management systems. Sci Total Environ. 2019;657:457-65.

23.Lima RP, Silva AP, Giarola NFB, Silva AR, Rolim MM, Keller T. Impact of initial bulk density and matric suction on compressive properties of two Oxisols under no-till. Soil Tillage Res. 2018;175:168-77.

24. Reichert JM, Rosa VT, Vogelmann ES, Rosa DP, Horn R, Reinert DJ, Sattler A, Denardin JE. Conceptual framework for capacity and intensity physical soil properties affected by short and long-term (14 years) continuous no-tillage and controlled traffic. Soil Tillage Res. 2016;158:123-36.

25.Nunes MR, Pauletto EA, Denardin JE, Suzuki LEAS, van Es HM. Dynamic changes in compressive properties and crop response after chisel tillage in a highly weathered soil. Soil Tillage Res. 2019;186:183-90.

26. Cardoso EJBN, Vasconcellos RLF, Bini D, Miyauchi MYH, Santos CA, Alves PRL, Paula AM, Nakatani AS, Pereira JM. Nogueira, M.A. Soil health: looking for suitable indicators. What should be considered to assess the effects of use and management on soil health? Sci Agric. 2013;70(4):274-89.

27.Embrapa. Sistema Brasileiro de Classificação de Solos. $3^{\circ}$ ed. Brasília, DF; 2013. 353 p.

28. Gonçalves D, Leite WC, Brinatti AM, Saab SDC, larosz KC, Mascarenhas YP, Carneiro PIB, Rosa JA. Mineralogia de um Latossolo Vermelho distrófico submetido a diferentes manejos por 24 anos. Rev Bras Ciência do Solo. 2008;32:2647-52.

29.Alvares CA, Stape JL, Sentelhas PC, Gonçalves JLM, Sparovek G. Köppen's climate classification map for Brazil. Meteorol Zeitschrift. 2013;22(6):711-28.

30.Embrapa. Manual de métodos de análise de solo. $2^{\circ}$ rev. Embrapa Solos. Rio Claro-SP: Embrapa Solos; 2011. 230 p.

31.Pavan MA, Bloch MF, Zempulski HC, Miyazawa M, Zocoler DC. Manual de análise química do solo e controle de qualidade. Londrina: Instituto Agronômico do paraná; 1992. 38 p.

32. Van Raij B, Quaggio JA, Silva N. Extraction of phosphorus, potassium, calcium, and magnesium from soils by anionexchange resin procedure. Commun Soil Sci Plant Anal. 1986;17:547-66.

33.Cantarella H, Quaggio JA, Van Raij B. Determinação da matéria orgânica. In: Van Raij B, Andrade JC, Cantarella $\mathrm{H}$, Quaggio JA. Análise química para avaliação da fertilidade de solos tropicais. Campinas-SP: Instituto Agronômico de Campinas; 2001. p. 173-80.

34.Bagarello V, lovino M, Elrick D. A simplified falling-head technique for rapid determination of field-saturated hydraulic conductivity. Soil Sci Soc Am Journal,. 2004;68(1):66-73.

35.Elrick DE, Reynolds WD. Methods for analyzing constant-head well permeameter data. Soil Sci Plant Nutr. 1992;56:320-3.

36.R Core Team. R: a language and environment for statistical computing. R Found Stat Comput. 2017.

37.Friendly M, Fox J. Candisc: visualizing generalized canonical discriminant and canonical correlation analysis. $R$ Packag version 06-3. 2013.

38. Dexter AR. Advances in characterization of soil structure. Soil Tillage Res.1988; 11(3-4):199-238.

39. Soracco CG, Lozano LA, Villarreal R, Melani E, Sarli GO. Temporal variation of soil physical quality under conventional and no-till systems. Rev Bras Ciência do Solo. 2018;42:1-12.

40.Bagarello V, Sgroi A. Using the simplified falling head technique to detect temporal changes in field-saturated hydraulic conductivity at the surface of a sandy loam soil. Soil Tillage Res. 2007;94:283-94.

41.Lima HV, Silva AS. Mesa de tensão com areia: procedimentos para montagem e validação. Rev Bras Cienc do Solo. 2008;32:2209-14.

42. Kabala C, Labaz B. Relationships between soil pH and base saturation - conclusions for Polish and international soil classifications. Soil Sci Annu. 2018;69(4):206-14. 
43.Manual de Adubação e Calagem para o Estado do Paraná. Sociedade Brasileira de Ciência do Solo. Curitiba, PR: SBCS/NEPAR; 2017. 482 p.

44. Miller RO, Kissel DE. Comparison of soil pH methods on soils of North America. Soil Sci Soc Am J. 2010;74:310-6.

45. Lisboa IP, Cherubin MR, Satiro LS, Siqueira-Neto M, Lima RP, Gmach MR, Wienhold BJ, Schmer MR, Jin VL, Cerri CC, Cerri CEP. Applying Soil Management Assessment Framework (SMAF) on short-term sugarcane straw removal in Brazil. Ind Crops Prod. 2019;129:175-84.

46. Luz FB, Silva VR, Mallmann FJK, Pires CAB, Debiasi H, Franchini JC, Cherubin MR. Monitoring soil quality changes in diversified agricultural cropping systems by the Soil Management Assessment Framework (SMAF) in southern Brazil. Agric Ecosyst Environ. 2019;281:100-10.

47. Cherubin MR, Tormena CA, Karlen DL. Soil quality evaluation using the Soil Management Assessment Framework (SMAF) in Brazilian Oxisols with contrasting texture. Rev Bras Ciência do Solo. 2017;41:1-18.

48.Cai A, Feng W, Zhang W, Xu M. Climate, soil texture, and soil types affect the contributions of fine- fraction-stabilized carbon to total soil organic carbon in different land uses across China. J Environ Manage. 2016;172:2-9.

49. Feng W, Plante AF, Six J. Improving estimates of maximal organic carbon stabilization by fine soil particles. Biogeochemistry. 2013;112:81-93.

50.Schmidt MWI, Torn MS, Abiven S, Dittmar T, Guggenberger G, Janssens IA, Kleber M, Kogel-Knabner I, Lehmann J, Manning DAC, Nannipieri P, Rasse DP, Weiner S, Trumbore SE. Persistence of soil organic matter as an ecosystem property. Nature. 2011;478:49-56.

51.Karlen DL, Andrews SS, Wienhold BJ, Zobeck TM. Soil Quality Assessment: Past, Present and Future. J Integr Biosci. 2008;6(1):3-14.

52.Rabot E, Wiesmeier M, Schlüter S, Vogel H. Soil structure as an indicator of soil functions: A review. Geoderma. 2018;314:122-37.

53.Cherubin MR, Karlen DL, Franco ALC, Tormena CA, Cerri CEP, Davies CA, Cerri CC. Soil physical quality response to sugarcane expansion in Brazil. Geoderma. 2016;267:156-68.

54. Bilibio WD, Corrêa GF, Borges EN. Atributos físicos e químicos de um Latossolo, sob diferentes sistemas de cultivo. Ciência e Agrotecnologia. 2010;34(4):817-22.

55.Tiecher T, Calegari A, Caner L, Rheinheimer DS. Soil fertility and nutrient budget after 23-years of different soil tillage systems and winter cover crops in a subtropical Oxisol. Geoderma. 2017;308:78-85.

56.Schick J, Bertol I, Barbosa FT, Miquelluti DJ, Cogo NP. Water erosion in a long-term soil management experiment with a Humic Cambisol. Rev Bras Ciência Solo. 2017;41:1-13.

57. Bertol I, Luciano RV, Bertol C, Bagio B. Nutrient and organic carbon losses, enrichment rate, and cost of water erosion. Rev Bras Ciência do Solo. 2017;41:1-15.

58. Husson $\mathrm{O}$. Redox potential ( Eh ) and pH as drivers of soil/plant/microorganism systems: a transdisciplinary overview pointing to integrative opportunities for agronomy. Plant Soil. 2013;362:389-417.

(C) (7) 8 ) 2020 by the authors. Submitted for possible open access publication under the terms and
conditions of the Creative Commons Attribution (CC BY NC) license
(https://creativecommons.org/licenses/by-nc/4.0/). 